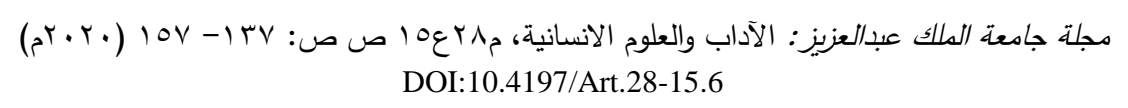

أثز المعنى والأداء على مسافة الصوت اللغوي الزمنية الرد على الدكتور

أحمد كثك في بحثه الموسوم من وظائف الصوت اللغوي أنموذجا

دراسة صوتية نقدية دلالية

$$
\begin{aligned}
& \text { د. لدمزم أحمد علي تقي } \\
& \text { الأستاذ المشارك بجامعة الملك عبد العزيز فرع السليمانية } \\
& \text { كلية الآداب قسم اللغنة العربية وآدابها }
\end{aligned}
$$

مستخلص. للمسافة الزمنية التي يستغرقها النطق بالصوت اللغوي داخل سياقه ضوابط تحددها عدة أمور منها مكان

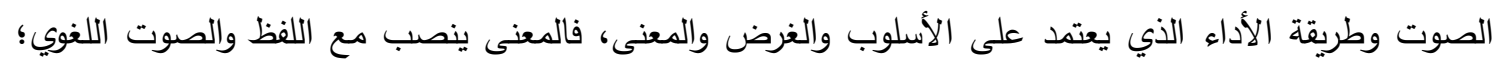

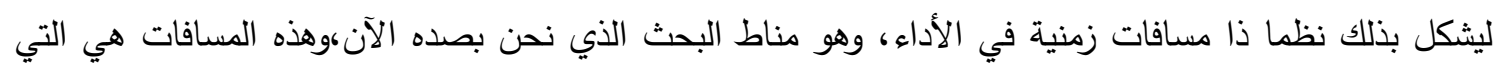

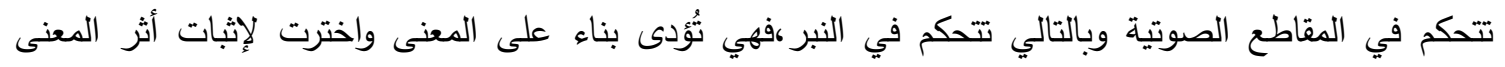

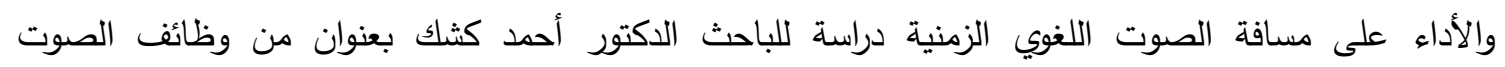

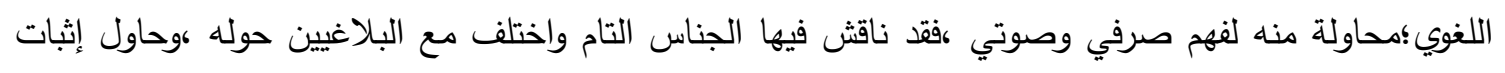

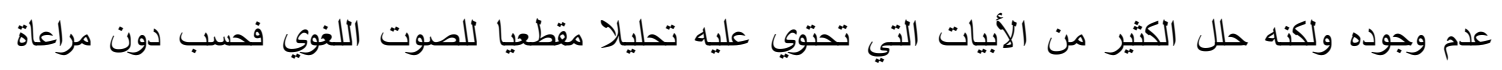

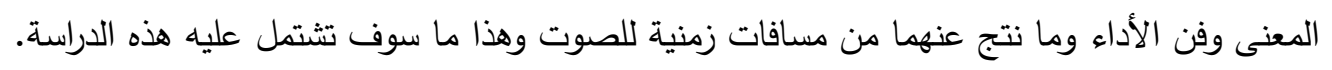

r- العلاقة بين المعنى والسياق والأسلوب وتلك

$$
\text { المسافات الزمنية؛ فهو الذي يحددها. }
$$

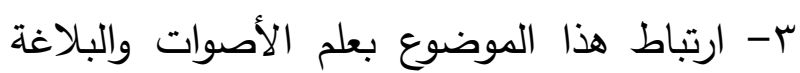
مما له الأثر الفعال على المعنى والأداء.

ع- نقد الدكتور أحمد كثك؛ لإثبات أثر المعنى المعنى

$$
\text { والأداء على مسافات الصوت الزمنية. }
$$

\section{المقدمة}

أسباب اختيار الموضوع: 1- أهمية المعنى والأداء وأثرهما على المسافات

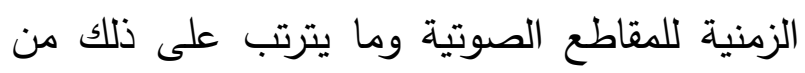
النبر والتنغيم. - النيه 
طبقت هذه الفكرة على الدراسة التي أجراها الدكتور أحمد كثك في بحثه الموسوم من و وظائف الصوت الصورت اللغوي وقد ذكرت محاولته الصوتية آنفا و وعدم لعند اعتباره لتلك المسافة الزمنية للصوت اللغوي التي تتأثر بالمعنى والأداء ؛لذلك اعتمدت في دراستي التيه التطبيقية على الأبيات التي اعتمد عليها، وسأبين

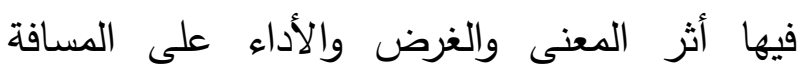
الزمنية للصوت اللغوي كما سيأتي. وبناء على ما سبق فقد تلخصت هيكلة البحث، فيما يلي :المقدمة وفيها نبذة عن الموضوع، والخطة، والمنهج، والخاتمة، وقائمة المصادر والمراجع. خطة البحث: تتكون من تمهيد عن المقاطع الصوتية ولثة، وفئية في العربية ومواضع النبر فيها، ومطلبين هما: المطلب الأول: الجانب النظري: وهو الأسس التي يقوم عليها فن الإلقاء وأثره على الصوت اللغول النوي.

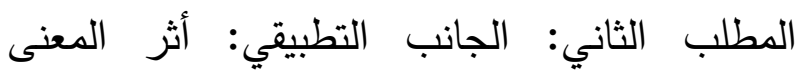
والأداء على مسافة الصوت اللغوي الزمنية من خلال

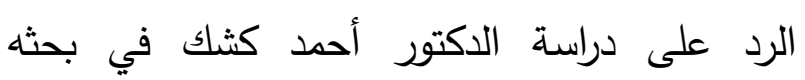
الموسوم من وظائف الصوت اللغوي. وسأتبع المنهج الوصفي التحليلي؛ إذ اخترت دراسة

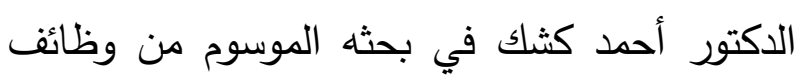
الصوت اللغوي إذ تكثف الدراسة عن أثر المسافة

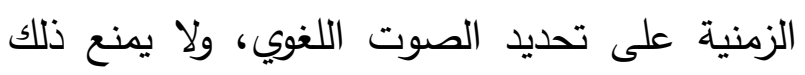
من استعمال مناهج أخرى حسبما تقتضيه طبيعة لحنيل البحث.
اعتمدت كتب الأصوات' في دراسة المقاطع الصوتية على النبر والتنغيم دراسة مقطعية لكل منهما، فالنبر يكون على مستوى المقطع الصوتي داخل الكلمة والتتغيم يكون على مستوى الكلمة داخل الجملة، كما تناولت كتب فن الإلقاء الأداء الصوتي لكل من لكني

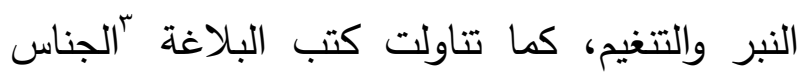
التام كنوع من أنواع الثراء اللغوي الذي تضفيه اللغة

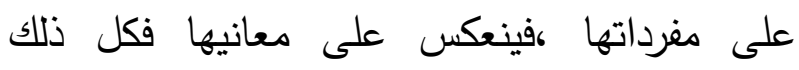
واضح ومعلوم ،ولكن الذي تضيفه هذه الدراسة هو

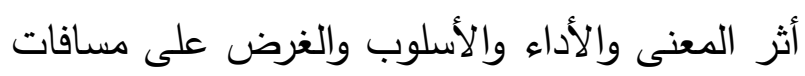

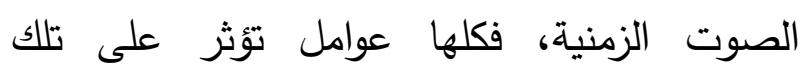
المسافات وتغير مقاطعها الصوتية تبعا لها كما سيتضح ذلك من خلال تلك الدراسة. أهداف البحث: ا- إثبات أثر المعنى والغرض على المقاطع الصوتية من حيث كمية مسافاتها r- إثبات اختلاف تلك المقاطع الصوتية تبعان كيه لاختلاف مسافاتها الزمنية التي تحدد أثكالها.

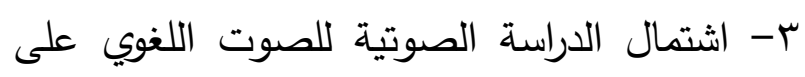

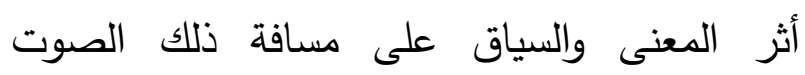

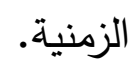

' انظر : أنيس إبر اهيم ،الأصوات اللغوية ،9V0 9 ، ،الطبعة الخامسة، مكتبة

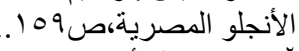

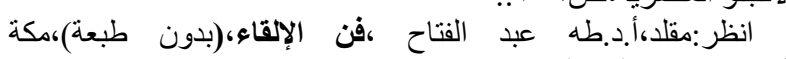

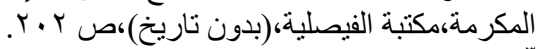

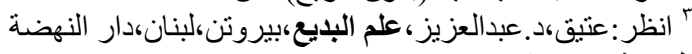

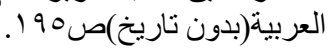




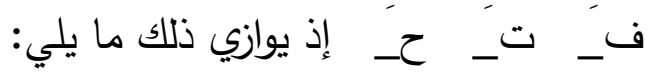
ص ح ص ح ص صح

ومثال المقطع الصوتي الساكن الصصدر (نَصْرُ) كإذ يتكون من مقطعين صوتيين ساكنين همال

كالآتي: - إن

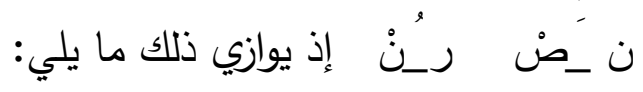

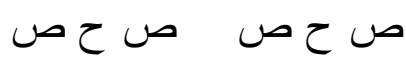

وتميل اللغة العربية إلى الأصوات الساكنة

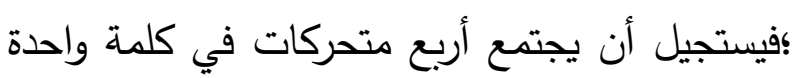

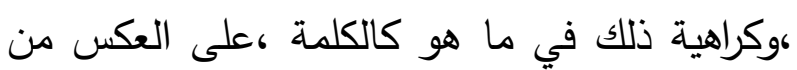
الأصوات الساكنة ؛إذ يصح أن تلتقي أربعة سواكن

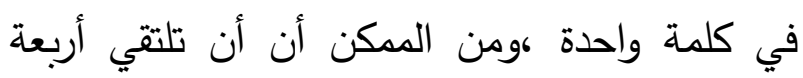

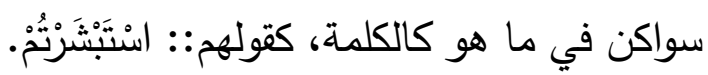

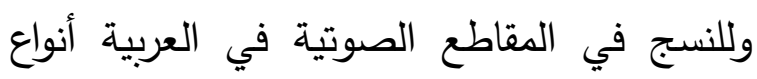

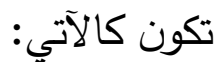

النوع الأول :يتكون من صوت ساكن وصوت لين

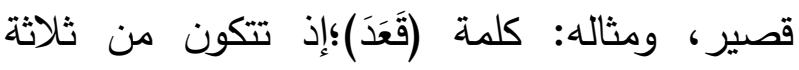
مقاطع صوتية تدثل هذا النوع ونسجها الصوتي

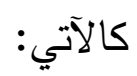

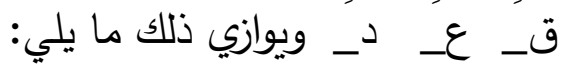

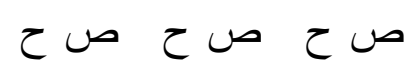
النوع الثاني: يتكون من صوت ساكن وصوت لين طويل، كالمقطع الصوتي الأول من كلمة (باع) ونسجه الصوتي كالآتي: ب ـ ـ ـ ويوازي ذلك ما يلي: ح ص
الخاتمة وفيها رصدت أهم النتائج والتوصيات، قفيتها بقائمة المصادر والمراجح. وختاما من لا يشكر الناس لا يشكر الله ؛الذا أود شكر سعادة الدكتورة الفاضلة ليلى عبدالله علي لإني باوزير التي أوحت لي بفكرة البحث من خلال نقاشنا للسافة الزمنية للصوت اللغوي وما يترتب على الأداء وفن الإلقاء من تاثير عليها ،وذكرت متفضلة بأني شاعرة وعروضية ؛الذلك سأكون جديرة بمعالجة تلك بلك الفكرة كما ينبغي ،فشكرتها على تلك الثقة وعزمت فئت جاهدة على السير قدما في إثبات تلك الفكرة التي أثبتتها الدراسات اللغوية الحديثة للصوت اللغوي إذا

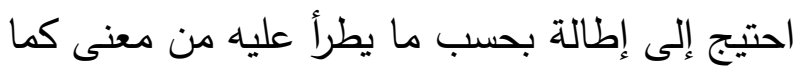

\section{(التمهيد (5)}

الدقاطع الصوتية في العربية ومواضع النبر فيها الدقطع الصوتي هو"حرف مع حركة أو حرفان ثانيهما ساكن"، ويتكون الهقطع الصوتي في العربية

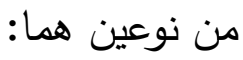
متحرك(Open)، وساكن(Closed)،فالمتحرك ينتهي بصوت لين قصير أو طويل ،بينما الساكن ينتهي ،لئي

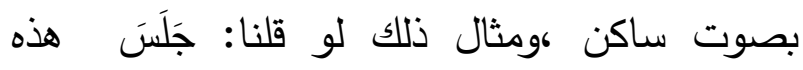
الكلمة تتكون من ثلاثة مقاطع صوتية متحركة :إذ تنتهي جميعها بصوت لين قصير وعند التقطيع

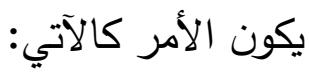

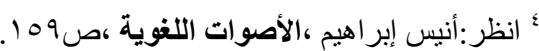

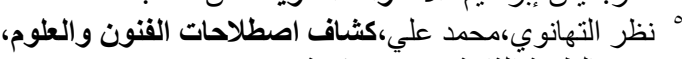

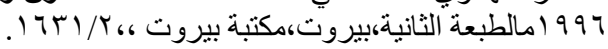


في وقت واحد كنشاط عضلات الرئتين وقوة حركات الوترين الصوتيين ؛إذ يقتربان من بعضهما حال النطق بالأصوات المجهورة ،فيتولد عن ذلك إنتاج عدد أكبر من الذبذبات الصوتية التي تنتج وضوحا في السمع لذلك المقطع الصوتي المنبور دون غيره من المقاطع الصوتية داخل الكلمة الواحدة، بينما

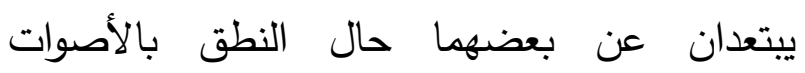
المهوسة؛ فيتولد عن ذلك تسرب مقدار أكبر من بالصدان الهواء بما يؤدي إلى وضوح ذلك المقطع الصوتي أيضا دون غيره في الكلمة العربية.

ولتحديد النبر في الكلمة العربية ننظر إلى المقطع

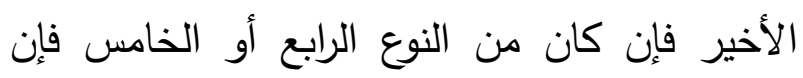

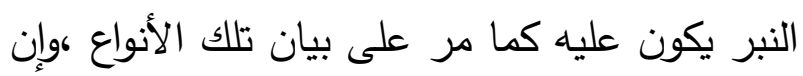

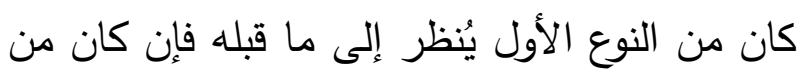
النوع الأول أيضا كان النبر عليه وذلك بحسب لاول عدنا لتلك المقاطع من الأخير ،ويكون النبر على المقطع

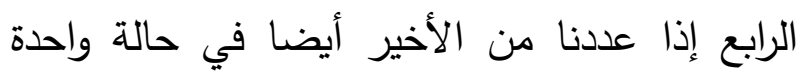
وذلك إذا كانت المقاطع الثلاثة التي قبل الأخير من التن

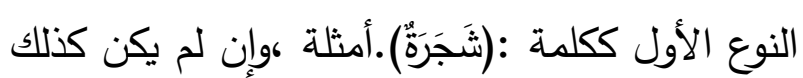

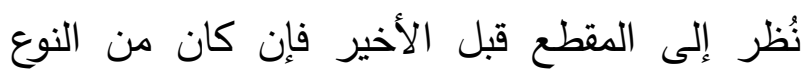

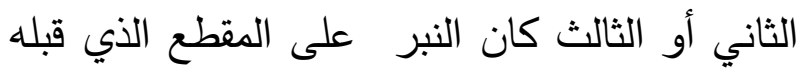

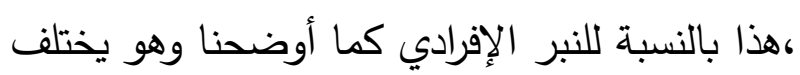
عن النبر السياقي الذي يكون على مستوى الجملة

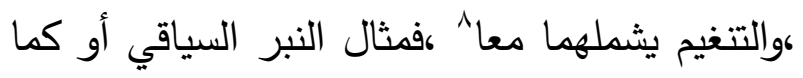
يسميه الدكتور إبراهيم أنيس بنبر الجمل :هو إبراز
النوع الثالث:يتكون من صوت ساكن وصوت لين

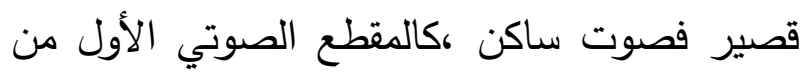
مثل القول:كُنُْْم،ونسجه الصوتي كالآتي: ك ــ ن ويوازي ذلك مايلي:

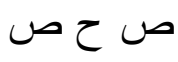
النوع الرابع:يتكون من صوت ساكن وصوت لين

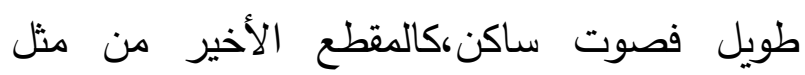
القول: نستبينُ حال الوقف عليه،ونسجه الصوتي كالآتي: ب = - _ ن ويوازي ذلك ما يلي: ص ص ح ص ص النوع الخامس : يتكون من صوت ساكن وصوت لين قصير فصوتين ساكنين، كالمقطع الأخير من كلمة: مستقرّ حال الوقف عليها، ونسجها الصوتي كالآتي:

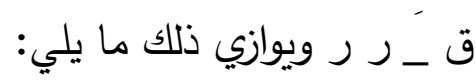
ص ح ص ص

وتعد الأنواع الثلاثة الأولى هي الأكثر شيوعا في

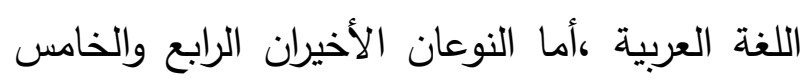
فيقل فيهما الشيوع ولا يكونان إلا في أواخر الكلمات التئن

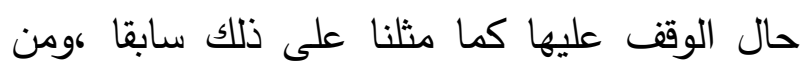
الجدير بالذكر أن الكلمة في اللغة العربية مهما

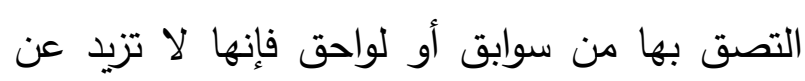

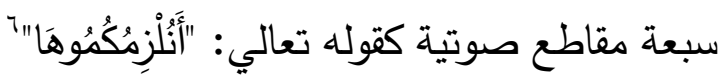

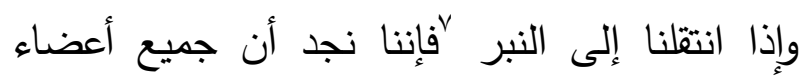
النطق تنشط عند النطق بالمقطع الصوتي المنبور 
والبيان من أهم الأمور التي يقوم عليها فن الإلقاء؛ فبهذا العنصر يتمكن المتلقي من معرفة ما يلقى إليه الهوريه

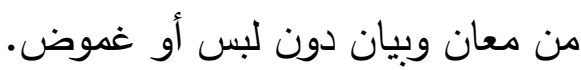
ومن الجدير بالذكر هنا التكلم عن مخارج الحروف وأبرز صفاتها الصوتية التي تمكن الملقي إذا أتقنها من جودة إلقائه وسهولة تواصله مع المتلقين ؛فلابد من الاهتمام بمخارج الحروف وصنفاتها الصوتية لهونية التي تميزها من همس وجهر ورقة وتفخيم وإطباق

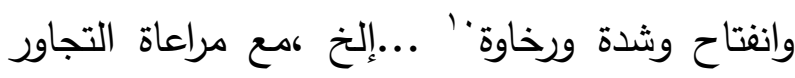
الصوتي بين تلك الحروف داخل الكلمات والجمل واتل التي تؤثر على صفات تلك الحروف ومن ثم طريقة أداء نطقها ،فكل ذلك يصب في جودة الأداء إن أحسن الملقي جميع تلك الأمور وذلك يحتاج إلى

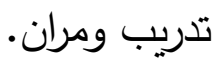

ويختلف نطق الحروف بحسب مخارجها كما قلنا ومن تلك المخارج سنذكر أبرزها إجمالا مع التوضيح

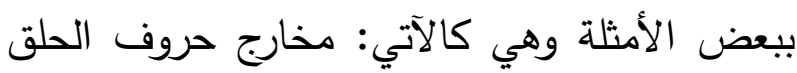
؛وهي التي تخرج من الحلق ،كالهمزة والهاء تخرجان من أقصى الحلق، والعين والحاء تخرجان من وسط لخط الحئ

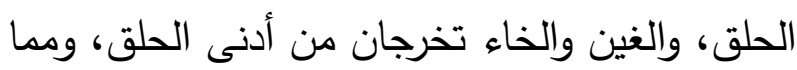
يخرج من أقصى الحنك مع أقصى اللسان القاف والكاف إلا أن القاف أدخل مخرجا من الكاف؛ فهو

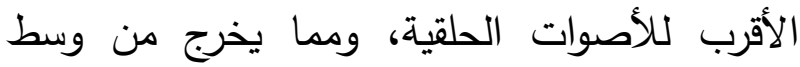
الحنك الأعلى مع وسط اللسان الجيم والثين والياء

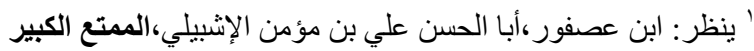

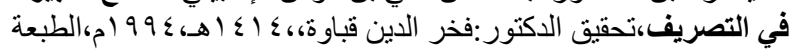

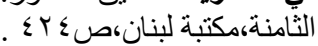

كلمة معينة في الجملة دون سواه بصورة سمعية واضحة مما يجعله يتناسب مع فرئه غرض المتكلم،

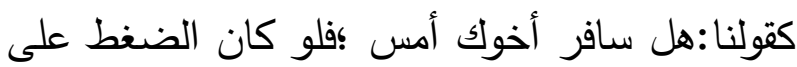
(سافر) لكان المتكلم شاكا في حدث السفر ، ولوكان

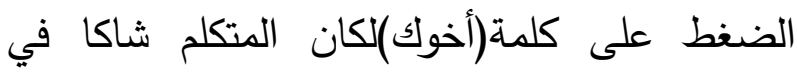

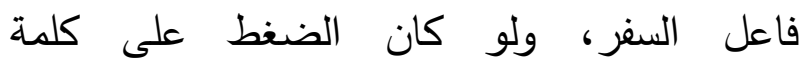
(أمس)كان المتكلم شاكا في تاريخ السفر وهكذا يختلف المراد من الجملة باختلاف النبر الجملي فيها. المطلب الأول: الجانب النظري:وهو الأسس التي

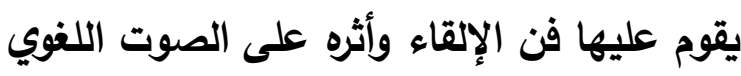
يعرف الاكتور طه فن الإلقاء بقوله: "هو فن إيضاح المعاني بالنطق والصوت؛ لكي تتوثق حلقة الاتصال

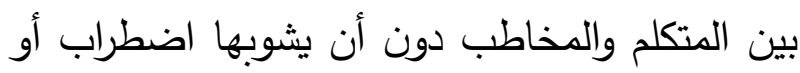
لبس حتى تأتي الصورة السمعية دقيقة في تفاصيلها"

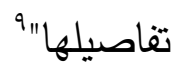
ومن خلال التعريف تبين لنا ثلاثة أمور يقوم عليها

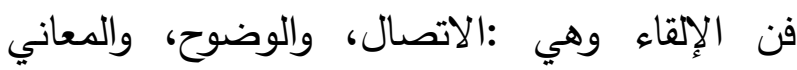
والبيان ؛فالاتصال يعتمد على الملقي والمتلقي فإذا لم ولماءل يتم الاتصال بينهما بوضوح سواء أكان اتصالا لعندي

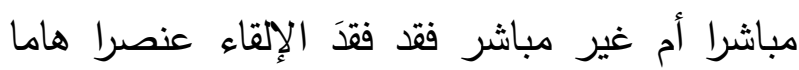
بينهما وهو التلقي، كما يعتمد الوضوح على خلو الملقي من الغموض واللبس الناتج عن اختلاف في اللهجة أو عيب في النطق، فلابد من وضوح مخارج الأصوات داخل الكلمات والجمل، كما تعد المعاني

ج انظر :مقلد طه عبد الفتاح،فن الإلقاء، / 1 1 1 
الههس من سكون وعدم تذبذب لتلك الحروف أثناء نطقها ،وكل ذلك يؤثر على الأداء سلبا أو إيجابا بحسب صحة ودقة نطقها، ومن تلك الصفات أيضا

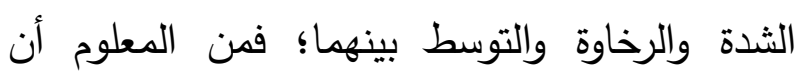
الأصوات التي تمتاز بالثدة تعد أقوى من التي تمتاز

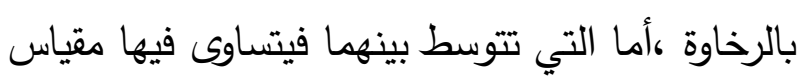

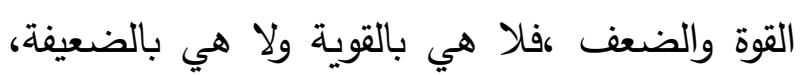

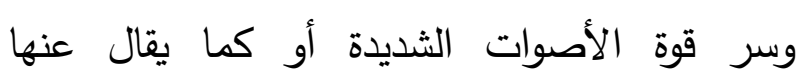
الانفجارية ما تحبسه من هواء يظل منحبسا خلف الفوات

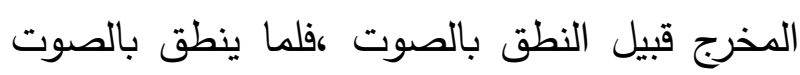

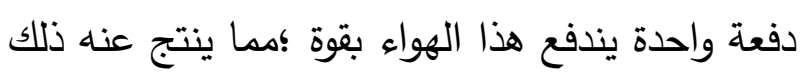
الانفجار ، وذلك عكس الأصوات الرخوة أو المتوسطة بين الثدة والرخاوة فكل منهما يسمح بمرور الهواء الهاء أثناء النطق بالصوت مما يجعلها أكثر احتكاكا

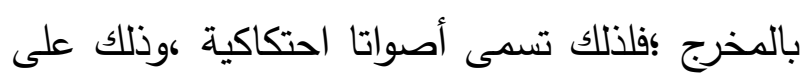

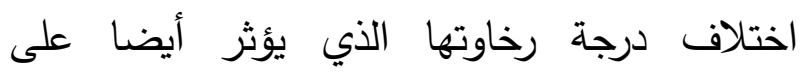

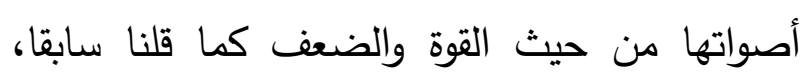
ومن تلك الصفات ايضا الاستعلاء والاستفال

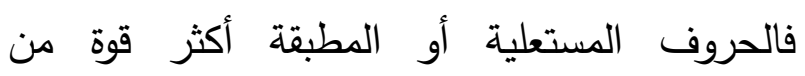

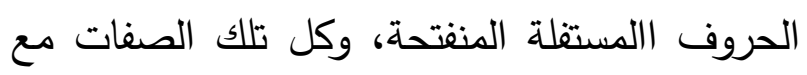
مخارجها تؤثر على الأداء والإلقاء سلبا أو إيجابا كما قلنا بحسب مهارة الملقي في نطقه تلك الحروف الداء نطقا سليما لمخارجه وصفاتها داخل كلماتها وجملها كم أوضحنا ذلك آنفا.

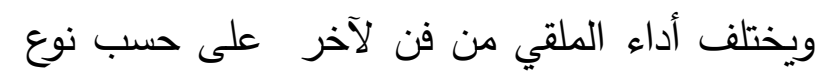

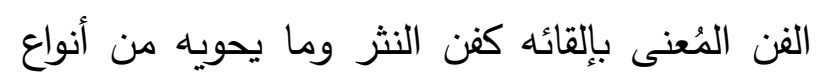

،ونقصد بالجيم تلك الجيم العربية الفصيحة وليست الجيم التي تتطق بالعامية أو الجيم القاهرية التي لتئي

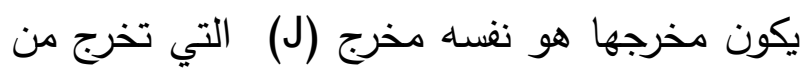

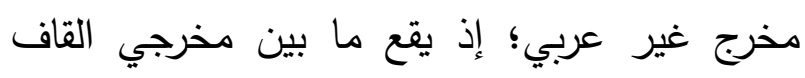

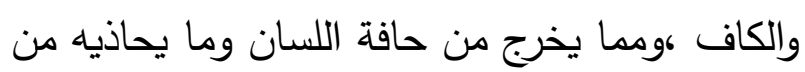
الأضراس الضاد العربية القديمة التي تختلف م حيث حيثل

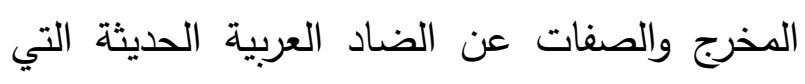

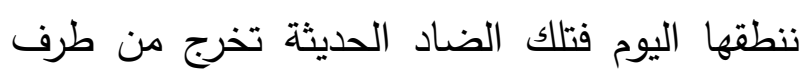

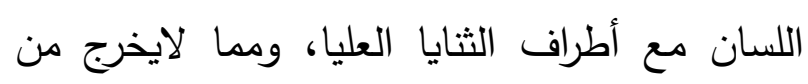
طرف اللسان وما يحاذيه من الحنك الأعلى اللام والنون والراء إلا أن الراء تبعد قليلا عن الحنك من الكان

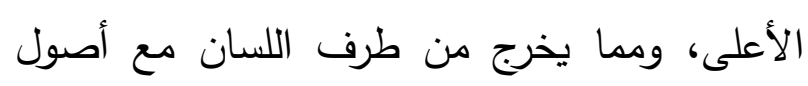
الثنايا العليا الطاء والدال والتاء والضاد التئ العربية الحديثة كما قلنا سابقا مع اختلاف صفاتها الصوتية في جميع ما ذكر وما سيذك من تلك الحروف، ومما يخرج من أطراف اللسان مع أطراف الثنايا العليا الثاء والظاء والذال، ومن الأصوا الثفوية التي تخرج من الثفه الفاء والباء والميم، ويختلف الجهر عن الاهواء

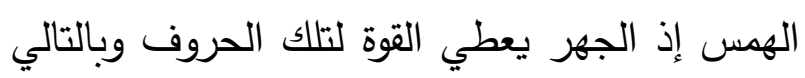
الكلمات التي تحتوي عليها تلك الحروف؛ بما ينتجه ذلك الجهر من ذبذبات صوتية ناتجة عن تحرك

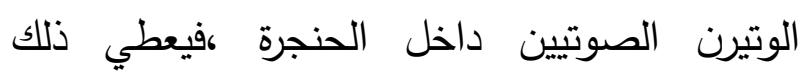
التحرك ترددات صوتية تتنقل عبر الهواء حتى تصل

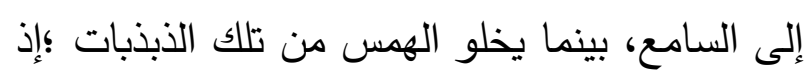
لا يتحرك الوتران الصوتييان في تلك الحروف التي لخي

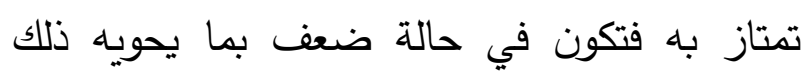


يكفي لكي يكون ملقيا جيدا ؛إذ لابد من الدربة والمران فأي مهارة لا تكتسب إلا بدربة تمكن مريدها من الوصول لهدفه المنشود. ومن الجدير بالذكر التكلم عن موسيقى البحر الشعرية ؛ولاسيما أنه سيكون التطبيق على المادة الثعرية في المطلب الثاني، وتختلف موسيقى الشعر تبعا لنوع التفعيلات داخل البحر ،ونوع البحر، وكذلك التغييرات التي تطرأ عليه ،فكل ذلك يؤثر في قوة البحر أو ضعفه بما ينعكس ذلك على الإلقاء فتتصيل ذلك ما يلي: تختلف موسيقى الثعر حسب نوع التفعيلات التي تكون ذلك البحر فالتفعيلات الخماسية أكثر انسيابا ورقة من السباعية بما تحويها من تكرار لها دون تنوع ففزا التماثل يجعلها أكثر رقة من سواها وهي تتوفر في فعولن في بحر المتقارب وفاعلن في المتدارك ،وقد تكون أكثر قوة إذا تتابعت معها التفعيلات السباعية كما في بحر الطويل الذي تتزاوج فيه تفعيلتا فعولن ومفاعيلن، وكذلك يتحكم نوع البحر في رقته أوقوته فالبحور المجزوءة أكثر رقة وانسيابا من البحور التامة، ومما يزيد من جمال تلك البحور وانسيابيتها وموسيقاها ما تحويـه من علل الزيادة التي لا تتوفر في البجور الطويلة كبحر الكامل الذي يشتمل مجزوءه على علل الزيادة كالترفيل والتذييل والتسبيع بما لا يشتمل عليها تامه فينتج عن ذلك نوع من الجمال والاتزان الموسيقي في القصيدة العربية، كما تعطي التغييرات التي تقع في تلك التفعيلات
وفن الشعر، وما يههنا هو فن الشعر ؛فملقي الشعر ينبغي أن يلم بجملة من الأمور تمكنه من إيصال ما يحسه الشاعر إلى المتلقي بسهولة ويسر ،وهي معنى القصيدة وما تحويـه من أوزان وقواف تحمل ألحانا وأحاسيسا تمثل تلك المعاني وتحفرها في ذهن المتلقي فتنساب إليه عذبة تتقل أحاسيس الثاعر إلى المتلقي بمنتهى اليسر والسهولة ،وذلك يحتاج كما قلنا إلى فهم معنى القصيدة ومناسبتها ،كما يعتمد على الأسلوب الذي صيغت عليه ؛فأسلوب الرثاء يختلف في الأداء عن أسلوب المدح أو الفخر ،وكذلك الغزل ،فنجد الرثاء مثلا يحتاج إلى التأمل مع ما يشوبه من أحاسيس الحزن والثجن إثر فراق ذلك الشخص المرثي،" وكذلك أسلوب الفخر يعتمد على جهارة الصوت ووضوحه مع تتوع التتغيم فيه ؛حتى يجذب السامع ويدفع الملل ،وكذلك يؤدي إلى التشويق، وكل ذلك يبرز أجمل الصفات للممدوح ،وكذلك الأمر لكافة الأساليب التي تقوم عليها القصائد بما تحويـه من معان وأغراض، وكل اختيار فيها من وزن وجرس وصوت يخدم تلك المعاني، ومما لا شك فيه أن فن الإلقاء هو من يبرز تلك المعاني بما يملكه الملقي من وسائل تجعله يتقن هذا الفن ،بما ذلك الموهبة الفطرية التي تمكنه من نطق مخارج الحروف وصفاتها داخل كلماتها وجملها بسهولة ويسر،هذا مع استعداده الشخصي ورغبته الصادقة في نييل تلك المهارة المنشودة ،وكل هذا لا " ينظر : الدكتور أنيس، إبر اهيم،موسيقى الثعر، به 90 1م،الطبعة الثنانية،

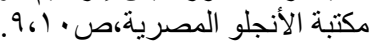


وبالتالي تختلف مواضع النبر فيهما؛ فلا يتحقق الجناس التام ،وتكون المقاطع الصوتية عنده كالآتي: لقائط واشِ

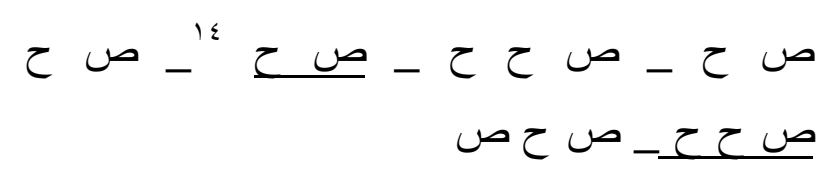
وذلك يختلف من حيث نوعية المقاطع المكونة له حن حله وبالتالي يختلف موقع النبر في قوله:لقاء طواشي؛إذ نإن تكون المقاطع الصوتية على النحو الآتي:

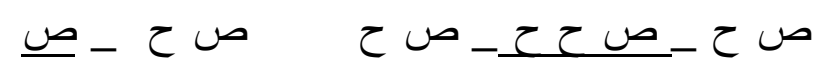

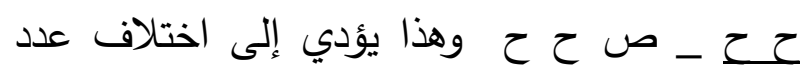

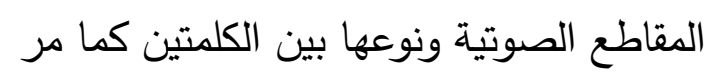
وعند النظر في تحليله نجد أنه راعى الناحية المقطعية الصوتية فحسب ولم يراع المسافة الزمنية الناتجة عن المعنى والسياق وذلك كما في الكلمتين

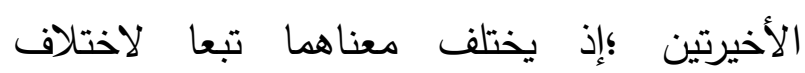
مقاطعهما الصوتية من حيث النوعية كما سنرى تبعا لاحئين للأداء وفن الإلقاء فيهما كالآتي: مقاطئ لقاء طواشي ص ص ص ح ح ح

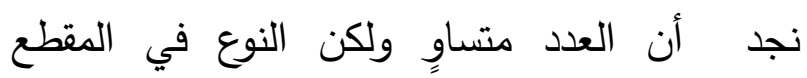
الصوتي الثاني يختلف بحسب المعنى ؛فالثاعر يريد أن يطمئن الحبيب بأن لا يخف من الوشاة؛ فهذا

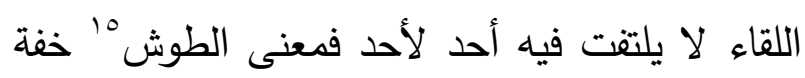

\footnotetext{
؛' الخط الذي تحت المقطع الصوتي يرمز لنبره.

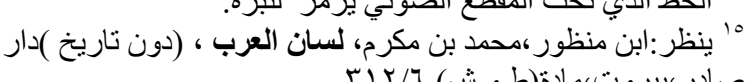

مزيدا من الرقة والانسيابية والموسيقى ما لا تعطيه

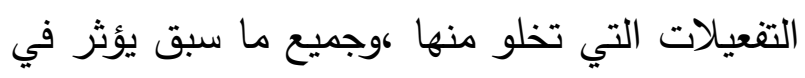
فن الإلقاء؛ إذ لابد للملقي من التمكن واكتساب المهارة والنظر في كل تلك العوامل التي تؤثر على الألى إلقائه.

المطلب الثاني: الجانب التطبيقي: أثر المعنى

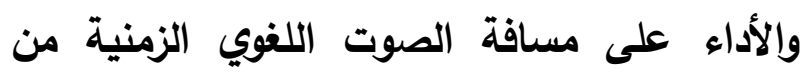
خلال الرد على دراسة الاكتور أحمد كثك في بحثه الموسوم من وظائف الصوت اللغوي سأتكلم في هذا الجانب عن أثر المعنى والأداء على وطن مسافة الصوت اللغوي الزمنية من خلال الأبيات التي تتاولها الدكتور أحمد كثك بالدراسة، حيث ذكر لترنية

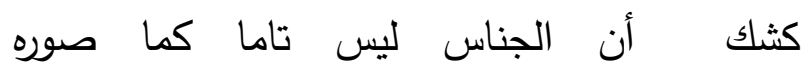

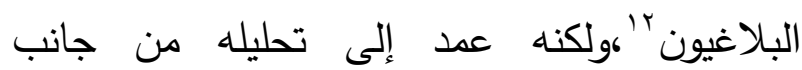
مقطعي صوتي فحسب ،ولم يراع السياق والدلالة ،والأداء الصوتي، والمسافة الزمنية للصوت اللغوي لئي المترتبة على جميع ما سبق، وكل ذلك سوف نناقشه

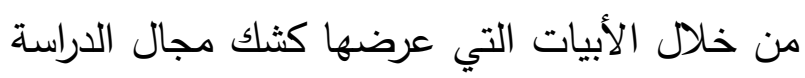
ونقوم بتحليلها على النحو الآتي:

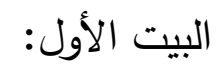

ونم في أمان بالحبيب ولا تخف

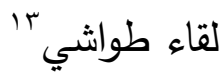
حيث ذكر كثك أن المماثلة بين لقائط واش و ولقاء طواشي غير حاصلة ؛إذ تختلف مقاطعهما الصوتية،

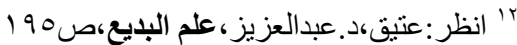

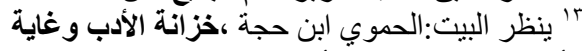

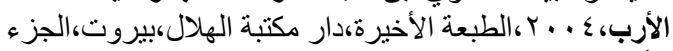
الأول،صفحة 


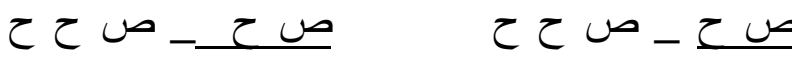
وهذا يؤدي إلى اختلاف عدد المقاطع الصوتية ؛فالتحليل الأول أثبت وجود أربعة مقاطع صوتية في

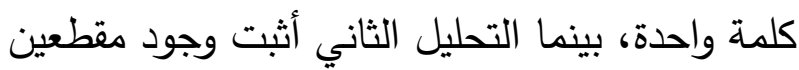
صوتيين في كلمتين كما مر . وعند النظر إلى تحليله نجد أنه راعى النين الناحية المقطعية الصوتية فحسب ،ولم يراع المسافة الزمنية للصوت اللغوي المتأثرة بالمعنى والسياق وذلك كما

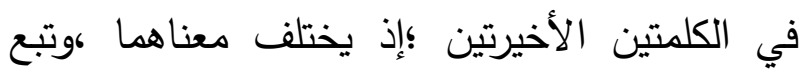
ذلك اختلاف مقاطعهما الصوتية من حيث عدد الصين المقاطع والكلمات ،فكل ذلك لا يتم إلا عن طريق

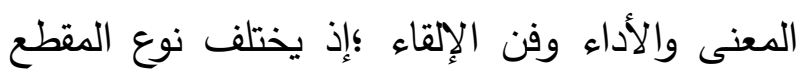
الصوتي تبعا لطوله الذي يوجبه المعنى؛ فالمقام مقام حزن على ما آلا إليه من ذل وهوان فتحاوره سائلة

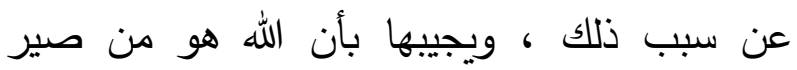

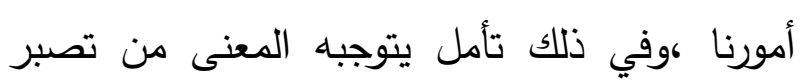

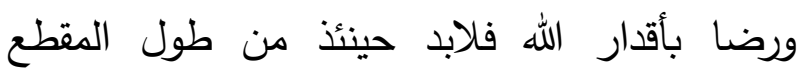

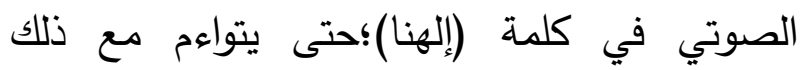
المعنى كالآتي: - المني إلهنا ص البيت الثالث وكم ساق في الظلماء والليل شاهد رواحلَ واطٍ

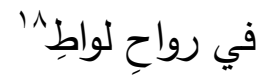

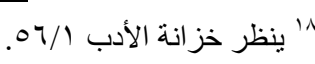

العقل والذي يناسب المعنى هنا هو كثرة الزحام بما

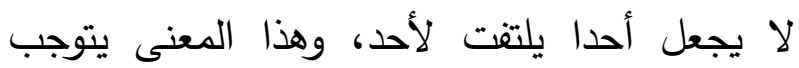

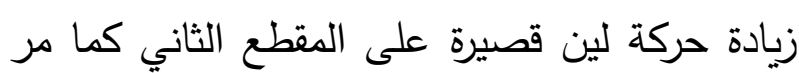

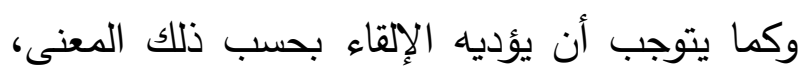
وهذا تبعا لإمكانية استطالة الصوت بحسب الإلب بودئ ما أثبتته الدراسات الفيزيائية ؛إذ يستطيل ذلك الصوت من

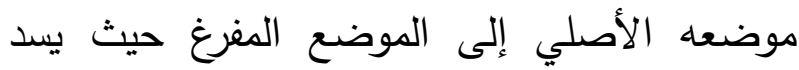

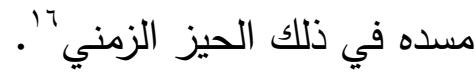
البيت الثاني - ماني قال لقد هُنَّا هنا مولاي أين جاهنا

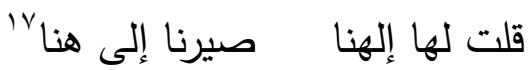
حيث ذكر كثك أن المماثلة الصوتية بين (إلهنا) و (إلى هنا) غير حاصلة ؛إذ تختلف مقاطعهما الصوتية، وبالتالي تختلف مواضع النبر فيهما ؛فلا يتحقق الجناس التام ،وتكون المقاطع الصوتية عنده كالآتي: - الآن إلهنا

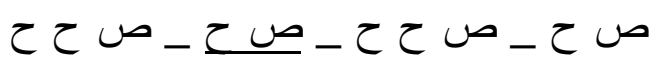
وذلك يختلف من حيث عدد المقاطع الصوتية ونوعيتها مقارنة بما سيماثلها من جناس تام كما

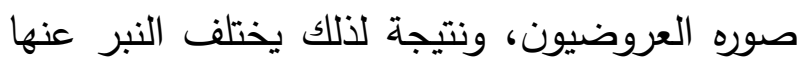
في قوله: إلى هنا؛ إذ تكون المقاطع الصوتية على

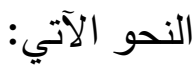

و' ينظر :د.باوزير ليلى عبدالله علي،التضام المقطعي إجراءاته

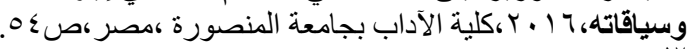

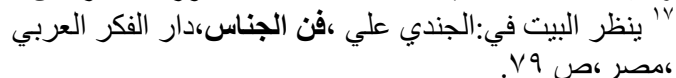


والتأمل؛ فالليل بظلامه يشتمل على أمور كثيرة

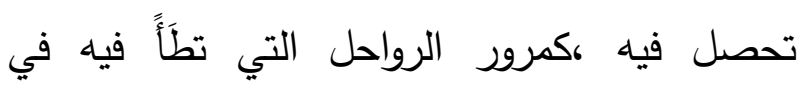
رواحه'19 وما يلزق فيه من المشاعر التي يكون

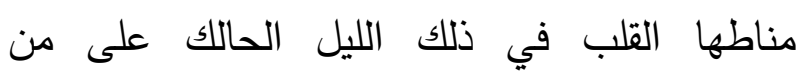
يستشعر الآهات فيه، وعلى هذا المعنى يتوجب أن أن يكون طول المقطع الصوتي في كلمة (رواح)؛حتى لهى يتواءم مع ذلك المعنى كالآتي: ص ح

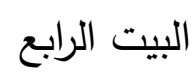
وأين إذا كان الفراق معاندي مطالعُ ناء في مطال

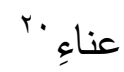

حيث ذكر كثك أن المماثلة الصوتية بين (مطالعُ

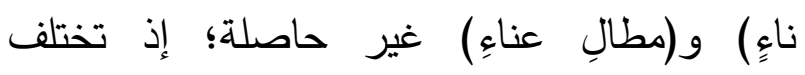

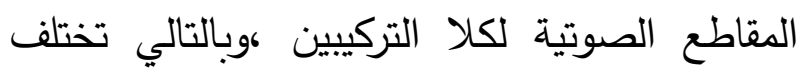
مواضع النبر فيهما فبذلك لا يتحقق الجناس التام ،وتكون المقاطع الصوتية عنده كالآتي: مطالعُ ناعِ

ص ص

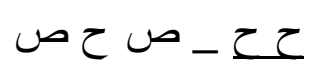
وذلك يختلف من حيث عدد المقاطع الصوتية ونوعيتها بترتيبها في موقعها الجديد المكون للكلمتين

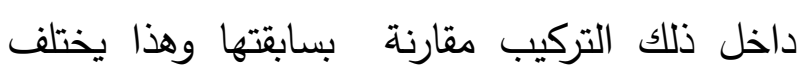
طبعا عما صوره العروضيون من التماثل التام

\footnotetext{
19 ينظر :لسان العرب، معنى الرواح:من لدن زو ال الثمس إلى الليل ،مادة

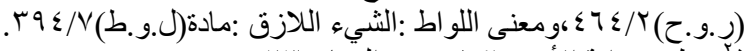

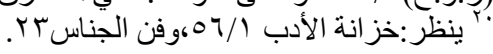

حيث ذكر كثك أن المماثلة الصوتية بين (رواحل

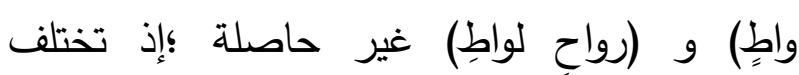
مقاطعهما الصوتية، وبالتالي تختلف مواضع النبر إنبر

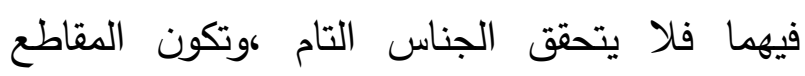
الصوتية عنده كالآتي: - الصفي رواحل واطٍ

ص ص ح حح_ص ح ص وذلك يختلف من حيث نوعية المقاطع الصوتية وكميتها من حيث وضعها الذي تكون عليه من كلمة

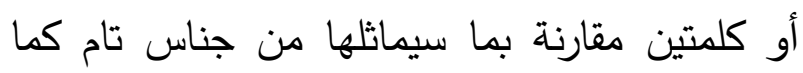

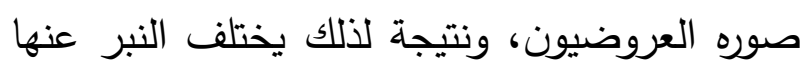
في قوله: رواح لواطِ؛ إذ تكون المقاطع الصوتية على ولى

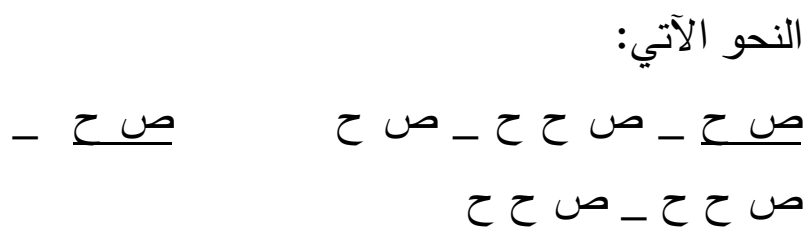
وعند النظر إلى تحليله نجد أنه راعى الناحية المقطعية الصوتية فحسب ،ولم يراع المسافة الزمنية

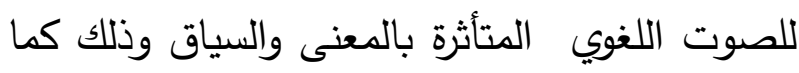

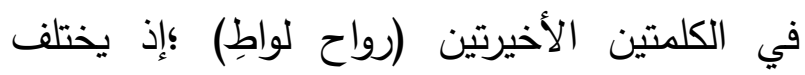

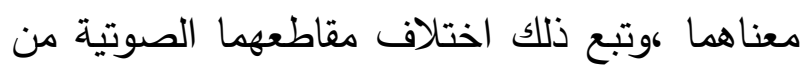

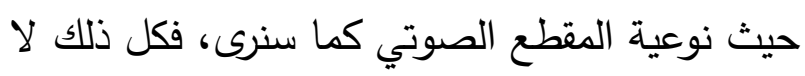

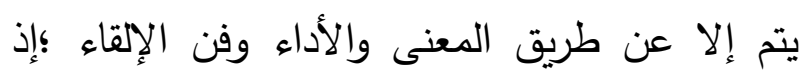
يختلف نوع المقطع الصوتي تبعا لطوله الذي يوجبه المعنى؛ فالمقام مقام حكمة وتأمل؛ لذلك استهل الثاعر بيته ب(كم) الخبرية التي تدل على الكثرة 
لكلا الكلمتين، وبالتالي تختلف مواضع النبر فيهما فبذلك لا يتحقق الجناس التام ،وتكون المقاطع

الصوتية عنده كالآتي:

ساكنًا

ص ح ح ص ص ح ص ص

وذلك يختلف من حيث عدد المقاطع الصوتية ونوعيتها بترتيبها في موقعها الجديد المكون لكلا الكلمتين المتجانستين ،وهذا يختلف طبعا عما صوره العروضيون دن التماثل التام للجناس التام ،وتكون المقاطع الصوتية للكلمة الثانية على النحو الآتي: ص ح ح وعند النظر إلى تحليله نجد أنه راعى الناحية المقطعية الصوتية فحسب ،ولم يراع المسافة الزمنية للصوت اللغوي المتأثرة بالمعنى والسياق وذلك كما في الكلمة الأخيرة (ساكنْ) ؛ إذ إنك لو تأملت المعنى لوجدت استطالة على المقطع لصوتي الأول بزيادة صوت لين قصير ناتج عن المعنى، والأداء ؛فالمقام مقام غزل ومحبة عارمة لذللك المحبوب الساكن اللامبالي بالقلب الذي يضطرب من شدة الوله بذلك المحبوب ؛لذلك كان الأحرى هنا زيادة صوت اللين على هذا المقطع والذي أيده هنا وزاد من جماله الموسيقي وأضفى دعما وتأملا لهذا المعنى وجود الترفيل بزيادة سبب خفيف على نهاية التقعيلة وهو من علل الزيادة المعروفة في بحر الكامل ،فهذه الزيادة دعمت من زيادة ذلك المقطع
للجناس التام ،وتكون المقاطع الصوتية للتركيب الثاني على النحو الآتي: ص ص ح ص ح ح وعند النظر إلى تحليله نجد أنه راعى الناحية المقطعية الصوتية فحسب ،ولم يراع المسافة الزمنية للصوت اللغوي المتأثرة بالمعنى والسياق وذلك كما في الكلمتين الأخيرتين (مطالِ عناءِ) ؛؛إذ يختلف معناهما ،وتبع ذلك اختلاف مقاطعهما الصوتية من حيث نوعية المقطع الصوتي كما سنرى، فكل ذلك لا يتم إلا عن طريق المعنى والأداء وفن الإلقاء ؛؛إذ يختلف نوع المقطع الصوتي تبعا لطوله الذي يوجبه المعنى؛ فالمقام مقام ألم وذكرى ؛إذ يتساءل الثاعر عن لقيا المحبوب كيف تكون والبعد يعانده مع المماطلة التي ينتج عنها عناء من ذلك البعد، وبما فيها من ألم لعدم التمكن من لقاء ذلك المحبوب، وعلى هذا المعنى يتوجب أن يكون طول المقطع الصوتي في كلمة (مطالِ)؛حتى يتواءم مع ذلك المعنى كالآتي: مطالِ ص ح-ح ح ح

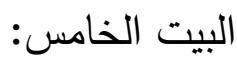
وسكنتَ قلبا خافقا يا ساكنًا في غير ساكنْ حيث ذكر كثك أن المماثلة الصوتية بين (ساكنًا) و(ساكن) غير حاصلة؛ إذ تختلف المقاطع الصوتية

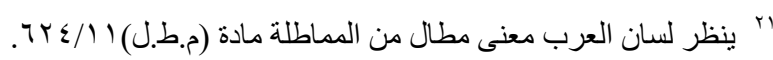




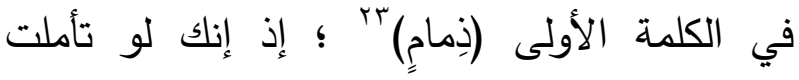
المنىى لوجدت استطالة على الدقطع الصوتي الثاني بزيادة صوت لين قصير ناتج عن المعنى، والأداء ؛فالمقام مقام حكمة وتامل ؛حيث استهل الثاعر بيته بالواو التي بمعنى رب حيث يرى أن صاحب

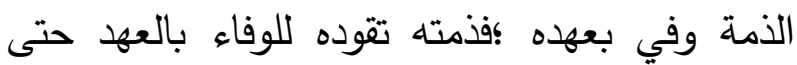
وإن كان لا يملك شيئًا؛ لذلك كان الأحرى هنا زيادة لكادة صوت اللين على هذا الدقطع، فزادت على أثران الثران المسافة الصوتية لذلك المقطع على النحو الآتي: ذِّمامٍ ص ح -ص البيت السابع:

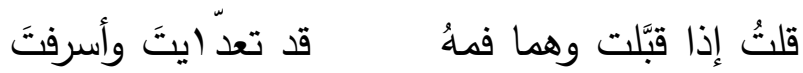
فمََهْ

حيث ذكر كثك أن المماثلة الصوتية بين

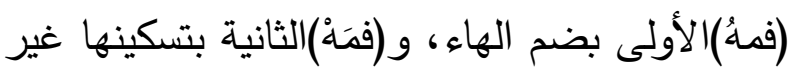
حاصلة ؛إذ تختلف الدقاطع الصوتية لكلا الكلمتين من حيث النوعية والكمية ،وتختلف بالتالي مواقع النبر فيهما فبذلك لا يتحقق الجناس التام ،وتكون

$$
\text { صفأ المقاطع الصوتية عنده كالآتي: }
$$

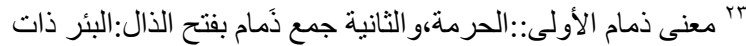

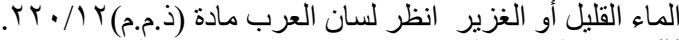

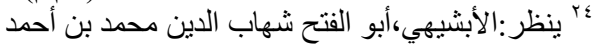

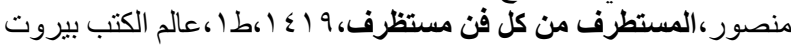

الصوتي كما ذكرنا بما خدم المعنى ،فزادت على أثره المسافة الصوتية لذلك الدقطع على النحو الآتي:

$$
\text { صاكنْ }
$$

وذني ذمامٍ وفت بالعهذ ذمته ولا ذمام له في

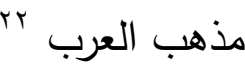

حيث ذكر كثك أن المماثلة الصوتية بين

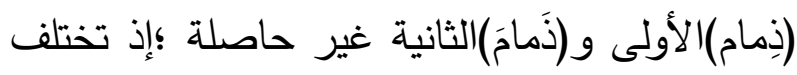
الدقاطع الصوتية لكلا الكلمتين ،وتختلف بالتالي مواقع النبر فيهما فبذلك لا يتحقق الجناس التام الكام كوتكون الدقاطع الصوتية عنده كالآتي:

لـ إِماحٍ

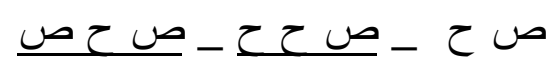

وذلك يختلف من حيث نوعية المقاطع الصوتية بترتيها في موقعها الجديد للكلمة الثانية التي كان من المفترض أن تكون مجانسة لسابقتها،وهذا يختلف طبعا عما صوره العروضيون من التماثل التام للجناس التام ،وتكون الدقاطع الصوتية للكلمة الثانية (نَمام) على النحو الآتي:

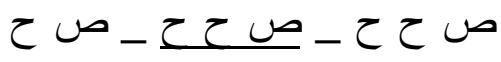
وعند النظر إلى تحليله نجد أنه راعى الناحية المقطعية الصوتية فحسب ،ولم يراع المسافة الزمنية

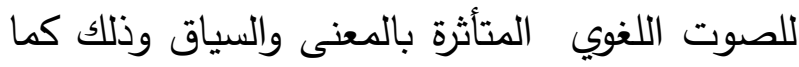


التام ،حتى لو لم تختلف المقاطع الصوتية هنا كوذلك كالآتي: حلالي و حلا لي

ح فقد اختلف النبر عن الكلمة الثانية حتى لو اتفتا من حيث عدد ونوعية المقاطع الصوتية ،إذ تكون مقاطع الكلمة الثانية الصوتية(حلا لي) على النحو الآتي: ص ح ح - ح وعند النظر إلى تحليله نجد أنه راعى الناحية المقطعية الصوتية فحسب ،ولم يراع المسافة الزمنية للصوت اللغوي المتأثرة بالمعنى والسياق وذلك كما في الكلمة الثانية(حلا لي) ؛ إذ إنك لو تأملت المعنى لوجدت استطالة على المقطع الصوتي الثاني من الكلمة الأولى منه بزيادة صوت لين قصير ناتج عن المعنى، والأداء ؛فالمقام مقام حكمة وعظة، فالحلال هو من يستحق أن يحلو في عين صاحبه وعلى هذا الأساس فقد حلا في عين الثاعر دون الحرام ،وإن كان الحرام يحلو في أعين الكثير دون الحلال والعياذ بالله- ؛فعلى هذا المعنى كان الأحرى هنا زيادة صوت اللين على هذا المقطع الصوتي،فتزبد على أثره المسافة الصوتية لذلك المقطع على النحو البيت التاسع:
وذلك يختلف من حيث نوعية المقاطع الصوتية بترتيبها في موقعها الجديد وكميتها للكمة الثانية التي كان من المفترض أن تكون مجانسة لسابقتها، وهذا يختلف طبعا عما صوره العروضيون من التماثل التام للجناس التام ،وتكون المقاطع الصوتية للكلمة الثانية (فَمَهْ)على النحو الآتي: ص ح- ص ح ص وعند النظر إلى تحليله نجد أنه راعى الناحية المقطعية الصوتية فحسب ،إن كان ما ذكره أتفق معه فيه من حيث مناسبته المعنى والأداء أيضا ؛فقد وافقت المقاطع الصوتية التي ذكرها الدكتور كشك المعنى والأداء ؛فالمقام دقام غزل إذ إن الثاعر يتمنى لو يقبل محبوبته لو حتى وهما ،بينما يقصر

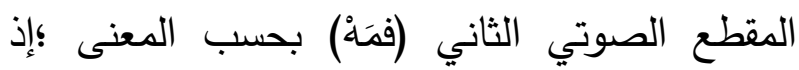
كأنه يلوم نفسه ويحاورها قائلا: فمهْ ؟ إذ يقول لنفسه اكففي ؛فأمر النفس بالتوقف عن فعل التقبيل ولو وهما يستوجب عدم الإطالة الصوتية وذلك حققه السكون الحاصل في في الكلمة الثانية كما رأينا. البيت الثامن: فمن يك يحلو له ما يصيب حراما فإن حلالي حلا ro حيث ذكر كثك أن المماثلة الصوتية بين (حلالي)الأولى و(حلا لي)الثانية غير حاصلة ؛إذ تختلف المقاطع الصوتية لكلا الكلمتين ،وتختلف بالتالي مواقع النبر فيهما فبذلك لا يتحقق الجناس 


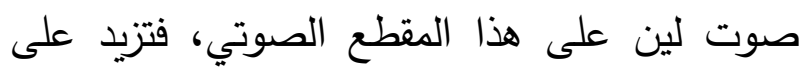
أثره الصسافة الصوتية للذلك المقطع على النحو الآتي:

فلاخ

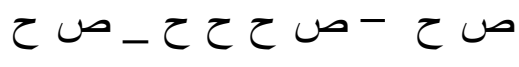

$$
\begin{aligned}
& \text { البيت العاشر: }
\end{aligned}
$$

إذا جرح العشاق قالوا قمت في مدار جراحٍ في

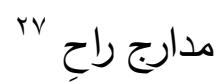

حيث ذكر الدكتور كثك أن المماثلة الصوتية بين

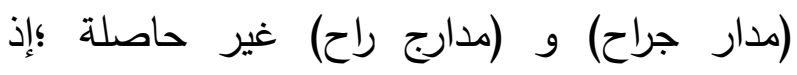

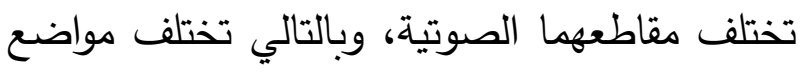
النبر فيهما ؛فلا يتحقق الجناس التام ،وتكون المقاطع الصوتية عنده كالآتي: مدار جراح ص ص ح ح $ح$

وذلك يختلف من حيث عدد المقاطع الصوتية

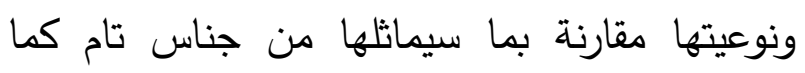
صوره العروضيون، ونتيجة لذلك يختلف النبر عنها في قوله: (مدارج راح)؛؛إذ تكون المقاطع الصوتية على النحو الآتي:

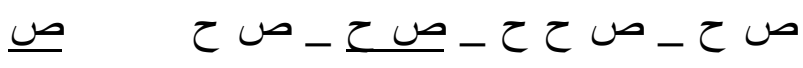

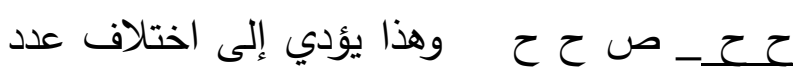

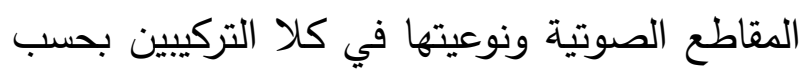
تكوين المقاطع الصوتية المكونة لكليهما.

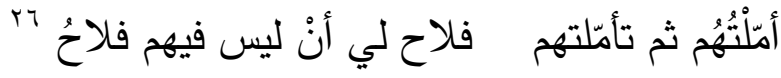

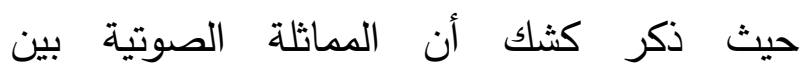

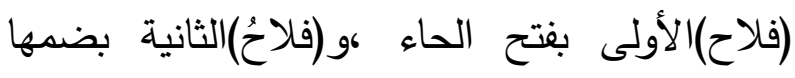
غير حاصلة ؛إذ تختلف نوعية المقاطع الصوتية لكلا الكلمتين ،وتختلف بالتالي مواقع النبر فيهما

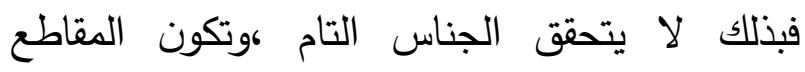
الصوتية عنده كالآتي: فلاخَ ح وذلك يختلف من حيث نوعية المقاطع الصوتية بترتيبها في موقعها الجديد للكلمة الثانية التي كان من المفترض أن تكون مجانسة لسابقتها، وهذا يختلف طبعا عما صوره العروضيون من التماثل التام للجناس التام ،وتكون المقاطع الصوتية للكلمة الثانية (فلاحُ)على النحو الآتي: ص ح ح ص ح ح ح $ح$ وعند النظر إلى تحليله نجد أنه راعى الناحية المقطعية الصوتية فحسب ،ولم يراع المسافة الزمنية للصوت اللغوي المتأثرة بالمعنى والسياق وذلك كما

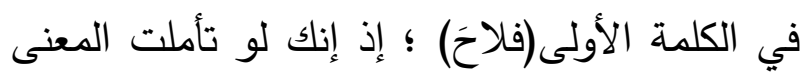

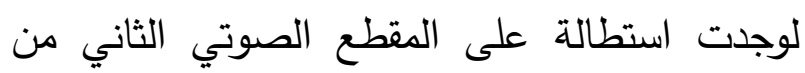

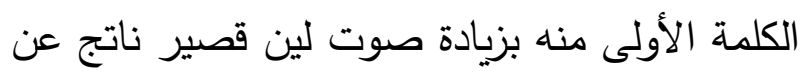
المعنى،والأداء ؛فالثاعر قد تأملهم مليّا ثم ظهر ولاح له أن ليس فلاح فيهم فهذا الاستتتاج يستوجب زيادة 


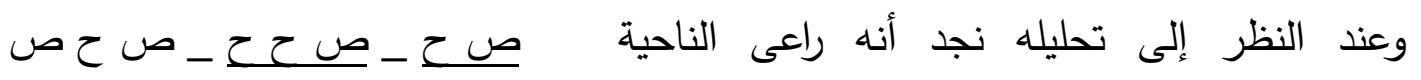
المقطعية الصوتية فحسب ،ولم يراع المسافة الزمنية ويختلف النبر عنها في قوله: (بنا بهُ)؛إذ تكون للصوت اللغوي المتأثرة بالمعنى والسياق وذلك كما المقاطع الصوتية على النحو الآتي:

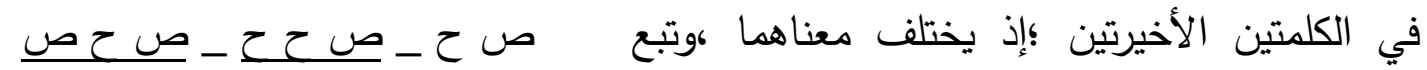
ذلك اختلاف مقاطعهما الصوتية من حيث عدد و وعند النظر إلى تحليله نجد أنه راعى الناحية

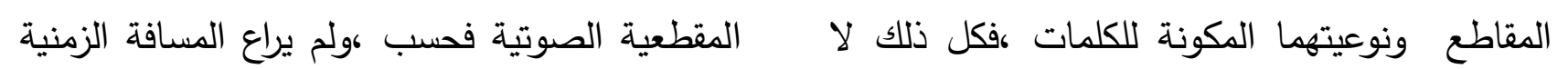

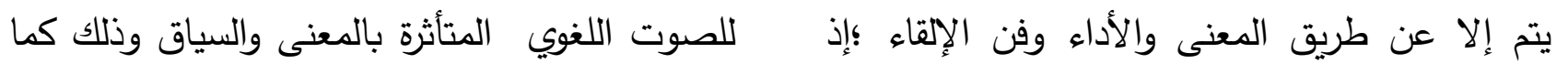
يختلف نوع المقطع الصوتي تبعا لطوله الذي يوجبه في الكلمتين الأخيرتين ؛إذ يختلف معناهما ،وتبع

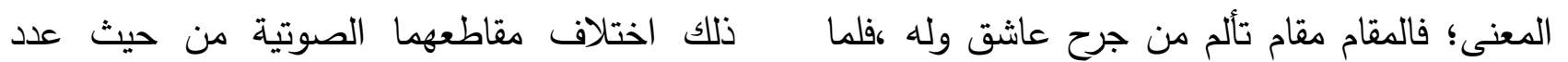

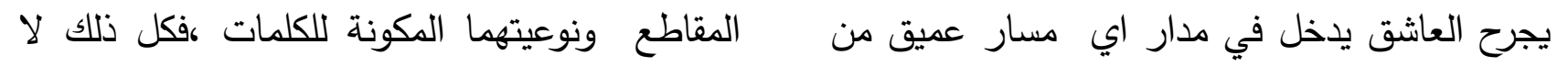

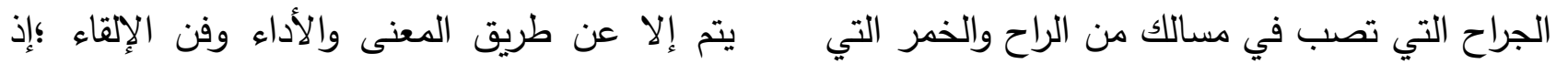
تجعله يهذي بها فلابد حينئذ من طول المقطع يختلف نوع المقطع الصوتي تبعا لطوله الذي يوجبه

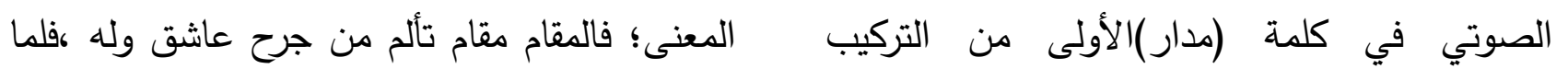

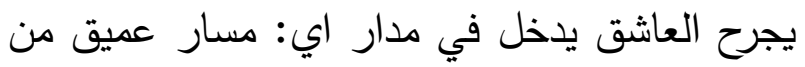

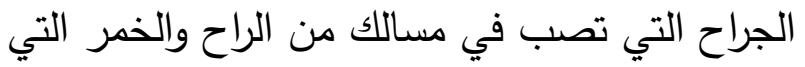
تجعله يهذي بها فلابد حينئذ من طول المقطع

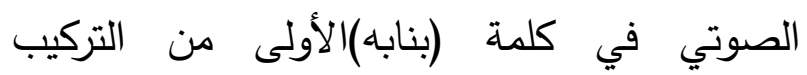
الأول؛حتى يتواءم مع ذلك المعنى كالآتي: بنابئ ص ح البيت الثاني عشر:

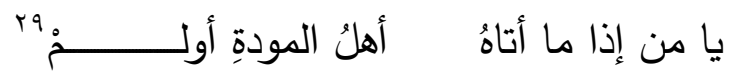

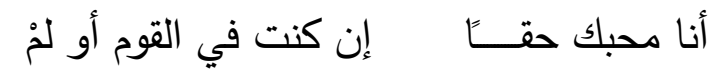
حيث ذكر الدكتور كثك أن المماثلة الصوتية بين (أولم) و (أو لم) حاصلة في المقاطع الصوتية الأول؛حتى يتواءم مع ذلك المعنى كالآتي: مدار ص ص ح ح ح ح البيت الحادي عشر:

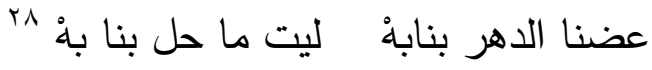
حيث ذكر الدكتور كثك أن المماثلة الصوتية بين (بنابه) و (بنا به) غير حاصلة وإن لم تختلف المقاطع الصوتية بينهما كمية ونوعا؛ وذلك لاختلاف مواقع النبر فيهما ؛لاختلاف التركيب النحوي بينهما كما هو واضح ،وتكون المقاطع الصوتية عنده كالآتي: بنابهُ 
أسرع وسر طالب المعالي بكل وادٍ وكل مهُمْهْr

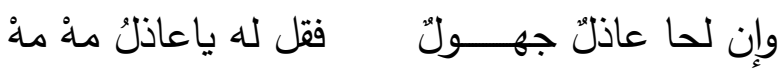
حيث ذكر الدكتور كثك أن المماثلة الصوتية غير حاصلة بين (مهمه) التي بمعنى :المفازة البعيدة

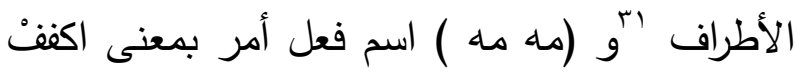

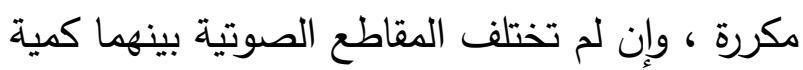
ونوعا؛ وذلك لاختلاف مواقع النبر فيهما ؛لاختلاف

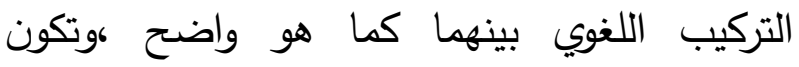
المقاطع الصوتية عنده كالآتي: بنابئ ص ح صـ_ص ص حصن صن ويختلف النبر عنها في قوله: (مه مه )؛؛ صإذ يكون على النحو الآتي: ص حص - ص ح ص الص وعند النظر إلى تحليله نجد أنه راعى الناحية المقطعية الصوتية وإن تتبه هنا إلى سكتة قبل مه مه تهد وعند النظر إلى المعنى نجد أن المسافة الزمنية متساوية بين المقطعين الصوتيين السابقين

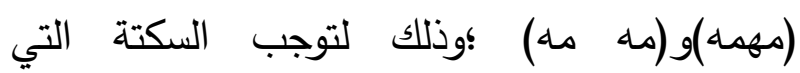
يقتضيها المقام بعد كلمة مه الأولى ؛فالثاعر يعذل كودل من يعذله بقوله اكفف فنيل المعالي يتوجب الإسراع لهاعل في الإجراءات التي تيسر الخوض فيه فلا مجال للعذل هنا وبسبب تلك السكتة تساوت المسافة الزمنية وإن اختلف النبر كما ذكر الدكتور كثك آنفا.

$$
\text { البيت الرابع عشر : }
$$

بينهما كمية ونوعاءمع اختلاف مواقع النبر فيهما ؛لاختلاف التركيب اللغوي بينهما كما هو واضح فالأولى تتكون من فعل والثانية من حرفين أولهما حرف عطف والثاني جزم ،وتكون المقاطع الصوتية عنده كالآتيفي الكلمة الأولى:

ص ح صـ_ص ص ح ويختلف النبر عنها في قوله: (أو لم)؛إذ يكون على صلى النحو الآتي: - ماني ص حص - ص حص صل وعند النظر إلى تحليله نجد أنه راعى الناحية المقطعية الصوتية فحسب ،وإن تساوت المسافة الزمنية للصوت اللغوي هنا؛ والذي أدى إلى هذان التهاوت التساوي وجود تلك السكتات التي يقتضيها المعنى والسياق أيضا فالممدوح محبوب سواء وُجدِ بين القوم أو لم يوجد بسبب كرمه وطيب خلقه، فتساوي محبته وجودا وعدما ساوت في التغني بمدحه وفي المسافة

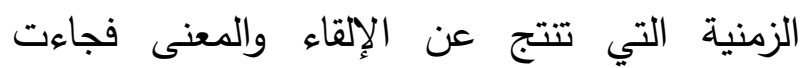

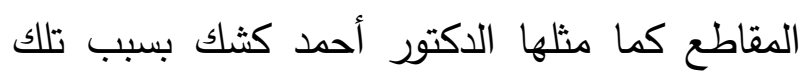
السكتات التي يتطلبها المعنى كما ذكرت آنفا، فتلك لكئك السكتات جاءت مناغمة لللك المعنى في حلة بحر المجتث الذي زاد من نغمها وتساوي مقاطعها على

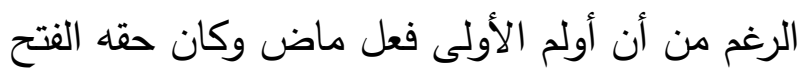

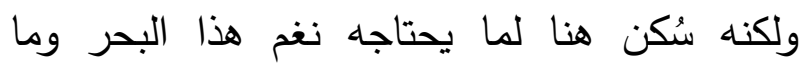
يقتضيه المعنى كما ذكرت. البيت الثالث عشر : 
عن أثر ذلك الحنين من نمو تلك المروج إثر هطول

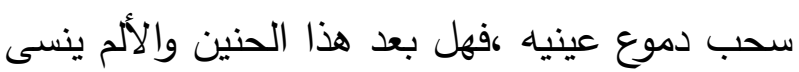

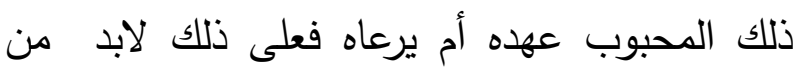

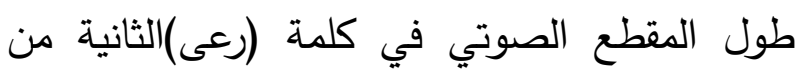
التركيب الثاني ؛حتى يتواءم مع ذلك المعنى كالآتي: بنابهُ ص حてص البيت الخامس عشر: كن كيف شئت عن الهوى لا أنتهي إلى الحياة وأنت هي كن كن كن حيث ذكر الدكتور كثك أن المماثلة الصوتية بين

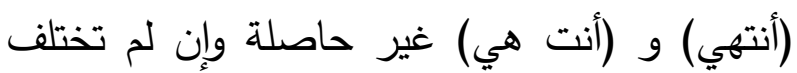
المقاطع الصوتية بينهما كمية ونوعا؛ وذلك لاختلاف مواقع النبر فيهما ؛لاختلاف التركيب الللغوي بينهما كما هو واضح ،ويكون اللنبر في الكلمة الأولىى

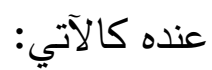
(أنتهي) ص حص ـ ص حـ_ ص ح ح $ح$ ويختلف النبر عنها في قوله: (أنت هي )؛؛ حإذ تكون المقاطع الصوتية على النحو الآتي:

$$
\text { ص ح حص ح صح }
$$

ومن الجدير بالذكر أن الدكتور كثك ذكر أثر

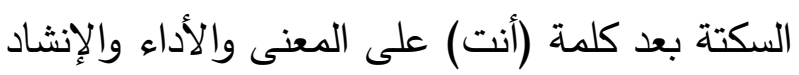
الذي نحن بهذا البحث بصدده وهذا مما لاشك فيه له له

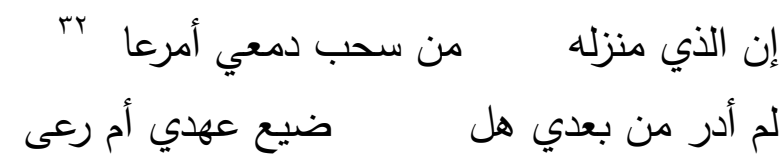
حيث ذكر الدكتور كثك أن المماثلة الصوتية بين

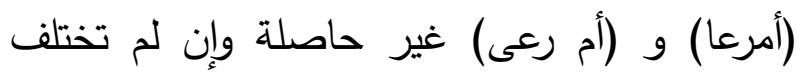

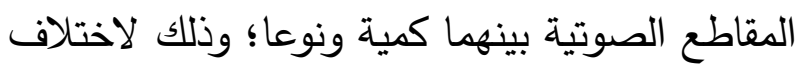
مواقع النبر فيهما ؛لاختلاف التركيب اللغوي بينهما كما هو واضح ،وتكون المقاطع الصوتية عنده كالآتي: بنابْه ص ح ص_ص ص ح ح ح ح

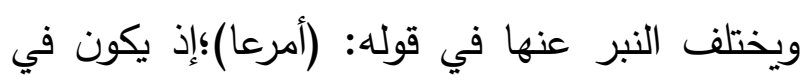
الكلمة الأولى على النحو الآتي:

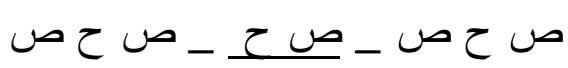
ويكون في التركيب الثاني على النحو الآتي:

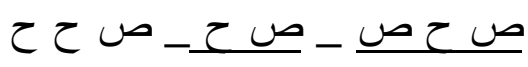
وعند النظر إلى تحليله نجد أنه راعى الناحية حلى حند المقطعية الصوتية فحسب ،ولم يراع المسافة الزمنية

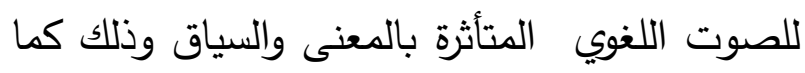

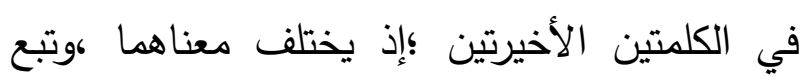
ذلك اختلاف مقاطعهما الصوتية من حيث عدد الصين

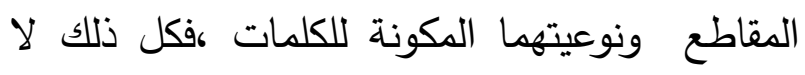

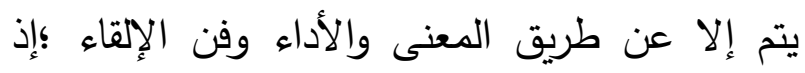

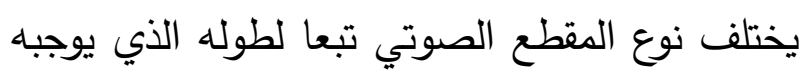

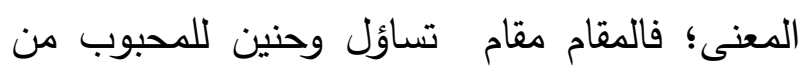
أثر البعد لارجة أن الثاعر رسم صورة بديعة ناتجة 
المسافة الزمنية للصوت اللغوي الناتجة عنه،وهذا بدوره يجعل تلك المقاطع الصوتية تتغير من حيث النوعية أو الكمية أي العدد داخل تراكيب الكلمات تبعا لاختلاف عددها داخل تلك التراكيب كما رأينا كوأثر المعنى والأداء على طول المقاطع فيها.

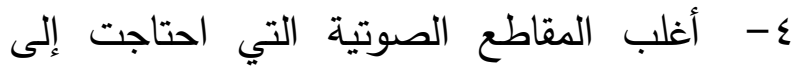
زيادة صوت لين قصير كانت في الكلمة الأولى من

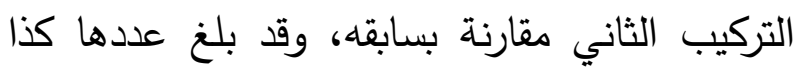
كما أوضحه البحث في البيت الأول والثاني والثالث والرابع والسادس والتاسع، وبعضها جاءت التهات بزيادة

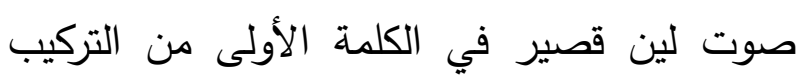

$$
\text { الأول كما في البيت العاشر. }
$$

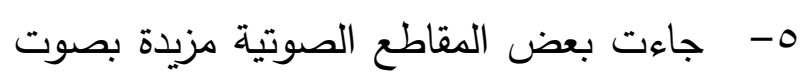

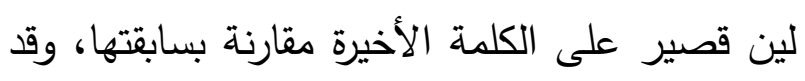

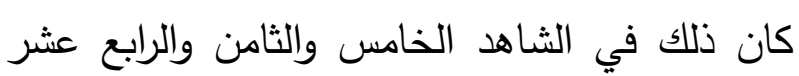
كما أوضحه البحث.

7- جاءت بعض المقاطع الصوتية مزيدة بصوت لين قصير على الكلمة الأولى، وهي الوحيدة المكونة

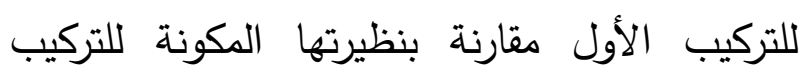

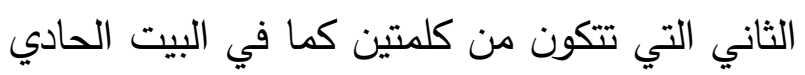
عشر.

- V - اتتقت معه في البيت السابع والثاني عشرة الثالث عشر من حيث عدد المقاطع الصوتية لكلا الكلمتين ،ولكنه ذكرها من ناحية مقطعية صوتية فحسب، وقد قمت بتحليلها من حيث المعنى والأداء.
بالغ الأثر على المعنى ؛فالثاعر كأنه يخاطب عاذله عن الهوى ذاكرا بأنه ماض فيه حتى تعود إليه

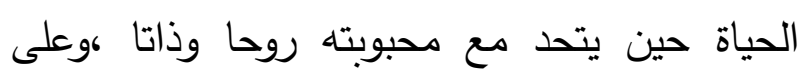

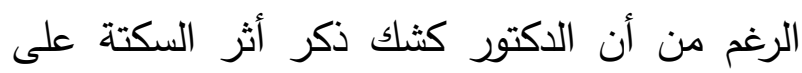

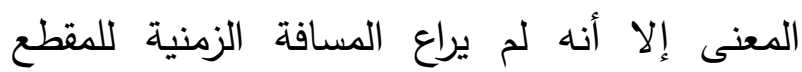
الصوتي الناتجة عن المعنى، التي كانت في هذه لإنه المرة خارجة عن الكلمتين اللتين تعبران عن الجناس

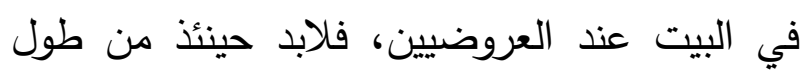

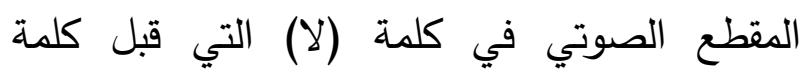

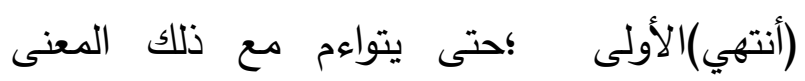

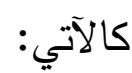
حてح ص

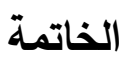

1- ذكر الدكتور أحمد كثك أن الجناس التام لم

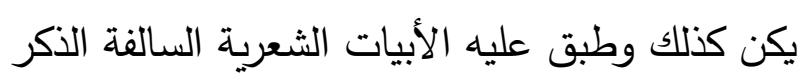
حيث أنكر أن يكون الجناس تاما كما صوره

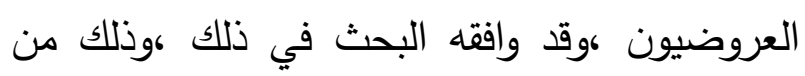

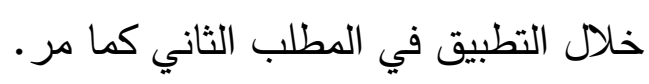
r- اعتمد الدكتور كثك في تحليله على الجانب المقطعي الصوتي فحسب ،ولم يراعِ المسافة الزمنية للصوت اللغوي التي نتجت عن المعنى والأداء الصوتي ؛إذ نتج عن ذلك اختلاف في عدد ونوعية المقاطع الصوتية. ץ- يعد المعنى هو المعيار في تحديد الأداء

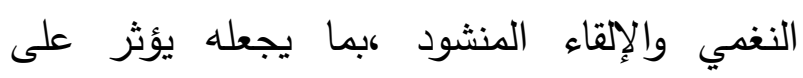


تعرض الدكتور كثلك لأثر السكتات على المعنى في البيت الخامس عشر.

rا-وجود علاقة وطيدة بين موسيقى الشعر العروضية والمعنى والأداء وأثر ذلك كله على الثى المسافة الصوتية لتلك المقاطع كما في البيت الثاني عشر ، وكذلك مع جمييع الأبيات لو تأملنا ذلك.

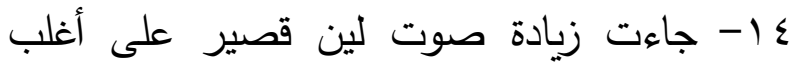
الدقاطع التي ناقشها البحث مما أخرجها عن الجناس

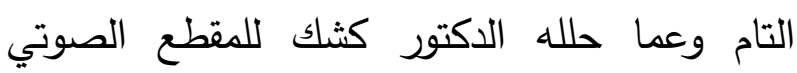
،واختلف الأمر في الثاهد الأخير الخامس عشر ؛ إذ جاءت الزيادة خارجة عن الكلمتين اللتين عدهما العروضيون جناسا تاما.

10- جاءت المسافة الزمنية للصوت اللغوي ثابتة

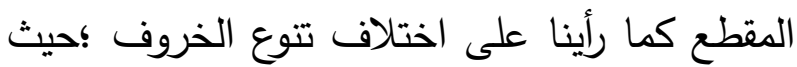

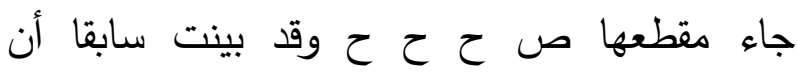
الدقاطع الصوتية العربية كانت ثابتة على خمس

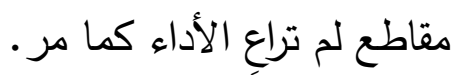
التوصيات

1- إعادة النظر في تحديد نوعية المقاطع الصوتية، ومسافاتها الزمنية تبعا للمعنى والأداء الناجم عن ذلك المعنى، وذلك يتوجب على من يعنى بعلم الأصوات أن يربطه في تحليله بالمعنى والأداء

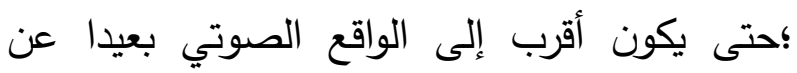
الاهتمام بالمقطع الصوتي فحسب وهذا ما لتا أثبتته الدراسات اللغوية الحديثة كما مرت الإثارة إليه في بحث الدتورة ليلى باوزير.
^- - أحيانا تتقق المقاطع الصوتية عند الاكتور كثك نوعية وكمية ،ولكنه لا يعدها جناسا تاما كما صورها البلاغيون مراعاة لاختلاف النبر بين تلك نلك

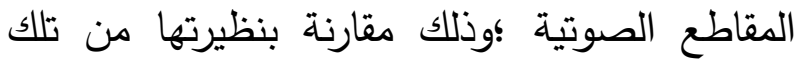
الدقاطع عنده كما مر في البيت الثامن، والحادي عشر والثاني عشر والثالث عشر والرابع عشر. 9- بض ولمض المقاطع الصوتية عنده تختلف من

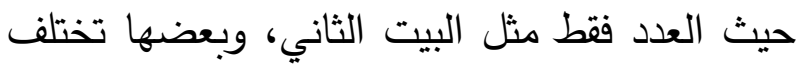
من حيث النوع فقط مثل البيت الأول والسادس

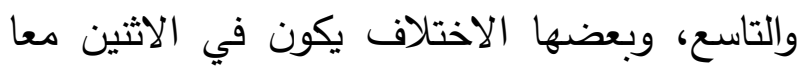
مثل البيت الثالث والرابع والخامس والسابع والعاشر . • 1- سبب الاختلاف في كمية الدقاطع الصوتية يكون وجود إحداهما في كلمة واحدة والأخرى في كلمتين كما مر ومن أمثلته البيت الثامن، والثالث عشر والخامس عشر. 11 - يُحكم بطول الدقطع أو قصره وبالتالي خروجه عن الجناس التام عدة أمور منها وجوده في كلمتين، أو بحسب المعنى أو السكتات التي يوجبها ذلكا المعنى كما رأينا ذلك في تحليل جميع الابيات.

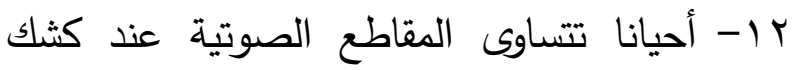
ولكن يختلف النبر عنده باختلاف نوعيهما لغويا ،وقد أثبت البحث أثر السكتات على المعنى وهذا لم لم يتعرض له كثلك في البيت الثاني عشر والثالث عشر والرابع عشر وإن اتفق البحث مع كثثك في البك نوعية العقاطع وخروجها عن الجناس التام، وقد 


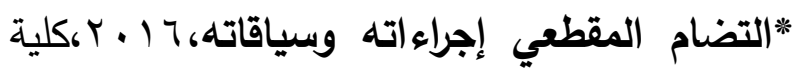

الآداب بجامعة المنصورة ،مصر • المعاء

ع - التهانوي،محمد علي.

*كثاف اصطلاحات الفنون والعلوم، 997 (مالطبعة

الثانية،بيروت،مكتبة بيروت

ه- الحموي ابن حجة

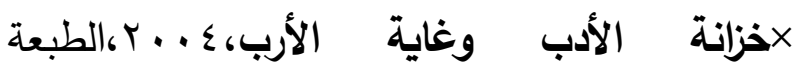

الأخيرة،دار مكتبة الهلاله،بيروت.

ז- الجندي علي.

"فن الجناس،دار الفكر العربي ،مصر •

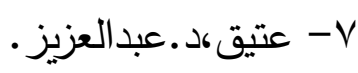

*علم البليع،بيروتن،لبنان،دار النهضة العربية(بدون

تاريخ)

1- ابن عصفور، أبا الحسن علي بن مؤمن

الإشبيلي.

*المتع الكبير في التصريف، تحقيق الدكتور:فر

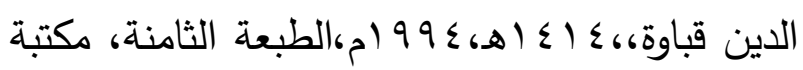

لبنان،

9-مقلد،أ.د.طه عبد الفتاح.

*فن الإلقاء،(بدون طبعة)،مكة المكرمة، مكتبة

$$
\text { الفيصلية،(بدون تاريخ). }
$$

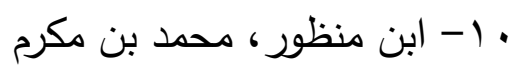

"لسان العرب ، (دون تاريخ )دار صادر ، بيروت. r- أن يعتمد تدريس الأبيات الشعرية على الإيقاع

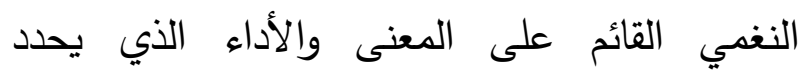

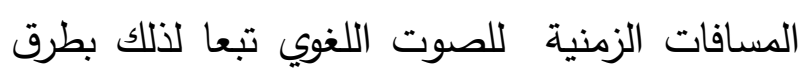
تطبيقية كما مر شرحها في المطلب الثاني.

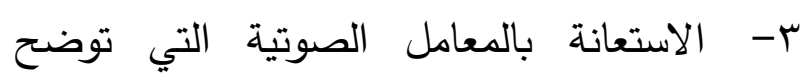
بطريقة عملية الفرق بين المقاطع الصوتية التي لا لالعانية

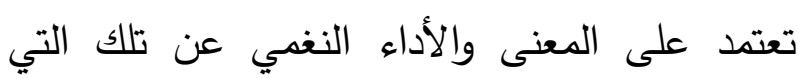
تعتمد عليهما ،بما يؤثر على المسافات الزمنية لتلك ولكي المقاطع الصوتية؛ وذلك سيكون أجدى فتيلا في تعلم فن الإلقاء في أي فن من الفنون الأدبية.

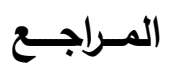

فهرس المصادر والمراجع '_الأبشيهي،أبو الفتح شهاب الدين محمد بن أحمد فئم منصور -

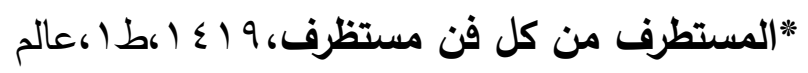

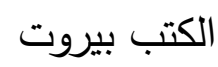
r--أنيس إبراهيم.

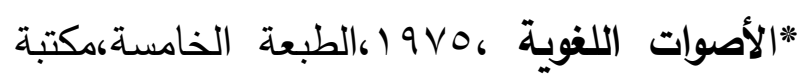
الأنجلو المصرية. * موسيقى الثعر،90r (90،الطبعة الثانية،مكتبة الأنجلو المصرية. r- د.باوزير ليلى عبدالله علي الهربه. 


\title{
The effect of meaning and performance on the linguistic sound distance of time The response to Dr. Ahmed Keshk in his research tagged of linguistic voice functions as a model Semantic Critical Voice Study
}

\author{
Dr. Zamzam Ahmed Ali Taqi \\ Associate Professor, King Abdulaziz University, Sulaymaniyah \\ Branch Faculty of Arts, Department of Arabic Language and Literature
}

\begin{abstract}
. the distance of time it takes to pronounce the linguistic sound within its context is determined by a number of things, including the location of the sound and the method of performance that depends on the style, purpose and meaning, the meaning focuses with the pronunciation and linguistic sound; To form systems with time distances in performance, which is the focus of the research that we are blocking now, and these distances are those that control the syllables and thus control the tone, they are performed based on the meaning and were chosen to establish the effect of the meaning and performance on the distance of the linguistic sound time a study by the researcher Dr. Ahmed Keshk Title of Linguistic Voice Jobs; An Attempt to Understanding Morphological and PhoneticIn it, he discussed the complete anagrams and disagreed with the rhetoric about it, and tried to prove his absence, but he analyzed many verses that contain a cross-sectional analysis of linguistic sound only without taking into account the meaning and art of performance and the resulting time distances for sound and this is what this study will include
\end{abstract}

